\section{Determining the Mental Estimation Strategies Used by Fourth-Grade Elementary Students in Four Basic Mathematical Operations}

\author{
Mustafa ULU1 ${ }^{1}$ Kemal ÖZDEMiR²
}

Received: $\quad 31$ May 2018
Revised: $\quad 25$ July 2018
Accepted: $\quad$ 05 September 2018
ISSN: $1307-9298$
Copyright $\odot$ IEJEE
www.iejee.com

DOI: 10.26822/iejee.2018143962

\begin{abstract}
It is aimed to determine the strategies used by the fourth-grade elementary students during the operational estimations in this research which is designed by using basic qualitative analysis. The study group consists of 26 fourth-grade students selected through convenience sampling method and attending at a state school which was located in the centre of Kütahya province during the 2016/2017 academic year. In order to determine the strategies used by the students while estimating the results of the basic mathematical operations, a 20-question scale consisting of 5 questions from each of the addition, subtraction, multiplication and division operations was developed. The research data were collected via semi-structured interview method. In the process of the data collection, students were asked to solve each question through using a method of thinking aloud and the interviews were recorded by a camera. The obtained records were sorted out as a part of elementary school program developed by the Ministry of National Education (MEB, 2005) by three specialists in elementary mathematics teaching according to strategies such as suggested rounding, grouping, using the front-end orders, using matched numbers, distribution, adjusting-rearranging and using algorithmic calculation. As a result of the research, it has been seen that the fourth-grade students mostly prefer the strategy of algorithmic calculation when making estimations in four basic operations. It has been also seen that fewer students used rounding, matched numbers, adjusting-rearranging in addition; rounding, adjusting-rearranging strategies in subtraction, multiplication and division mentioned by MEB (2005). It has been seen that students who obtained solutions using the strategies determined by MEB (2005), were realistic and estimated the result of the operation in a very short time, whereas students who preferred algorithmic calculation strategy, often had unrealistic results and long estimation spans.
\end{abstract}

Keywords: Estimation strategies, fluency in four basic mathematical operations, Elementary mental calculation, number sense.

\section{Introduction}

One of the most important skills used by people to solve problems which they encounter in their lifetimes is calculation (Olkun, 2015, Altun, 2006, Gülbağcl-Dede \& Şengül, 2014). It is stated that we sometimes calculate by using some instruments (paper-pencil, calculator,computer) but we mostly do mental calculation in our daily lives (Reys, Reys, Nohda \& Emori, 1995; Yazgan, Bintaş \& Altun, 2002; Gülbağcı-Dede \& Şengül, 2016). Çavuş-Erdem and Duran (2015) identified that illiterate individuals could make the calculations of money in their daily lives by developing original mental calculation strategies. The study conducted by Nunes, Carraher and Schliemann (1993) indicated that even though children who peddle with their parents on streets have difficulty with school mathematics, they could calculate mentally without a mistake by developing different strategies in the forms of the same questions transformed into street mathematics. The findings reached by Çavuş-Erdem and Duran (2015) and Nunes et al. (1993) help us see that mental calculation skills are developed depending on the daily life needs.

Previous studies have shown that individuals acquire the skill of consecutive counting at the ages of 2-3, but they do not comprehend the cardinal value of the number until they are about 5 years old (Olkun, Fidan \& Babacan-Özer, 2013; Griffin et al., 1994; Griffin \& Case 1997). With the comprehension of number's cardinal value, 5-year-old children start to solve problems by using the strategies of one-to-one correspondence (Olkun et al., 2013), physical calculation (using fingers and objects) or counting on (Griffin et al., 1994; Griffin \& Case 1997). Altun, Dönmez, İnan, Taner and Özdilek (2001) found that preschool students develop informal strategies for the solution to word problems to come up with the right answer. Considering that 5-6-year-old children are not able to calculate on paper, it can be said that mental calculation skills are started to be used at early ages (Olkun et al., 2013; Griffin, Case \& Siegler, 1994; Griffin \& Case 1997; Altun et al., 2001). When individuals start elementary school, rule-based written algorithms (calculation with paper-pencil) are added to their calculation strategies. When Dowker (2005) asked a student, who subtracted by breaking up ten and achieve the right answer, why he/she did that operation, the student said "I do not know; our teacher told us to do so." Therefore, rule-based algorithms are regarded as obstacles in front of the development of advanced mathematical skills even though they lead to the right answer (Baki \& Kartal; 2004, Anderson, 2010; Brynes \& Wasik 1991).

It has been found that a majority of elementary students mentally calculate in a rule-based manner when they learn the algorithmic calculation strategy, and this not only in-

\footnotetext{
Mustafa Ulu, Dumlupinar University, Faculty of Education, Department of Educational Science, Kutahya, Turkey. E-mail: mustafa.ulu@dpu.edu.tr Phone: +90 (274) 265-2031

2 PhD Student, Dumlupinar University, Faculty of Education, E-mail: kemalzdmr@yahoo.com
} 
creases the number of wrong solutions but also hinders the strategy development (Alsawaie, 2011; Harç, 2010; Şengül \& Gülbağcı-Dede, 2012; Çekirdekçi, Şengül \& Doğan, 2016; Jordan, Glutting \& Ramineni, 2009; Mohamed \& Johnny, 2010; Çontay \& İymen, 2011). Çavuş-Erdem and Duran (2015) determined that the algorithmic calculation skills are also frequently preferred by individuals who graduate and start to work, and these individuals seek for paper-pencil when they have trouble in calculating mentally. On the other hand, it has been determined that a majority of teachers (Gülbağcı-Dede \& Şengül, 2016a; Yang, Reys \& Reys, 2009) and pre-service teachers (Kayhan-Altay and Umay, 2011; Şengül \& Gülbağci, 2013; Gülbağcı-Dede \&Şengül, 2016; Artut, 2015; Er and Artut, 2016), like children, use rule-based strategies when calculating mentally. Given that students develop their solution strategies taking their teachers as models, teachers need to show that calculation can be done by multiple strategies to prevent over-regularization (Benjamin 2011; Keçeci, 2011; Rubenstein, 2001). Because it is stated that mental calculation skills affect both quality of life (Olkun, 2015; Altun, 2006; Gülbağcı-Dede \& Şengül, 2014; Çavuş-Erdem \& Duran, 2015; Nunes et al., 1993) and mathematical achievement (Harç, 2010; Şengül \& Gülbağcl, 2012; Yang, Li \& Lin, 2008; Çekirdekçi, Şengül \& Doğan, 2016).

Current educational systems emphasize that students should be provided with the opportunities of developing different strategies for the development of their mental calculation skills (Chinese National Mathematics Curriculum, 2001; National Council of Teachers of Mathematics, 2000; Australian Education Council, 1991; MEB, 2005). It is also observed that mental calculation skills are related to problem solving (Olkun, Yıldız, Sarı, Uçar \& Aybala-Turan, 2014; Yıldızlar, 2012; Geary, 2003) and reasoning skills (Gürbüz \& Erdem, 2016) which are suggested to be brought to students within the scope of the Mathematics course. It is supposed that the fact that the teachers encourage students not just to use paper-pencil but to utilize mental calculation strategies in the solution of problems that require calculation will contribute to the development of their flexible thinking skills (Gülbağcı-Dede \& Şengül, 2016; Olkun \& Uçar, 2014). It was observed that a great number of students use the strategy of writing mathematical sentence which has strict rules such as algorithmic calculation skill when solving real-life problems but fail and students who use different strategies such as trial and error, looking for a pattern, making a systematic list succeed (Ulu, 2017a). In the study conducted by Soylu and Soylu (2006), the question "Ali has 10 apples left after giving 5 of them to Ayşe. So, how many apples has Ali had in the first place?" was answered " $10-5=5$ " by most of the students. The interviews indicated that over-regularization of the phrase "apples left" caused the students to perform subtraction instead of addition. This led to the idea that the development of flexible thinking should be gained along with the first-learned calculation skills. In this context, the Australian Education Council (1991) decided that four basic mathematical operations are initially taught to students through mental calculation skills which facilitate using different strategies and then rule-based algorithms are implemented for developing flexible thinking skills at early ages.

According to Halmos (1980), strategic thinking is accepted as the heart of mathematics. Schoenfeld (2005) likens each strategy used to a key and the right solutions to a door which is unlocked. He stated that students cannot open different doors with the same key at each time and it would be a loss of time for them to try each key individually, emphasizing the necessity of choosing the right key for the right door. Accordingly, it is expected from the students to be aware of the strategies, to use their strategies flexibly, that is, to be conscious about a specific strategy to achieve a solution to a certain situation. Russell (2000:55) stated that flexible thinking skill can be easily developed at early ages and adduced the interviews with two students who did the wrong solution by using the algorithmic calculation strategy.

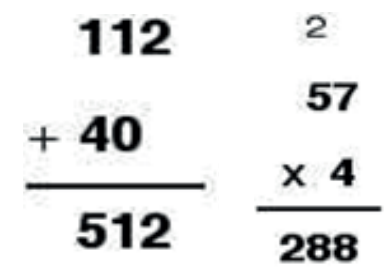

One of the students thought that she applied all the rules in the operation correctly, but then reported that the solution was incorrect. She could not find the source of the error in the solution; however, she stated that the answer was not reasonable. The student was asked to calculate 110+40 mentally; she added 4 tens to $110(120,130,140,150)$ to achieve the answer and then added the 2 which she did not include in the operation to 150 and achieve the right answer.

The other student mistook the rule and carried the 2 in the operation $4 \times 7=28$ and then added the carry 2 to the 5 in the tens digit found 288 . When the student was asked to calculate mentally, he first found $50 \times 4=200$. Thinking that he did not include $4 \times 7=28$ in the solution, he added 28 to 200 and found 228 .

These two solutions show that students whose first preference is the algorithmic calculation strategy can start to use mental calculation strategies with guidance in a short time (Russell, 2000:55). The first of the prerequisite skills needed to gain different strategies during the mental calculation process is considered as number sense (Griffin, Case \& Siegler, 1994; Griffin \& Case 1997; NCTM, 2000). Number sense is defined as the ability to use numbers and operations in a flexible manner in the most general sense (Şengül \& Gülbağcı-Dede, 2013; Nickerson \& Whitacre; 2008). According to Russell (2000), based on the abovementioned examples, flexible use of numbers is being able to express 112 as $110+2$ and 57 as $50+7$. Russell (2000) gave the solution provided by a student who tried to calculate 159/13 mentally as an example for the flexible use of operations. Accordingly, the student consecutively subtracted 13s from 159 and made a correct calculation and found that there are twelve $13 \mathrm{~s}$ in 159 with a remainder of 3. It can be said that the student solved a calculation to be made by division through subtraction by thinking it flexibly as she comprehended the connection between subtraction and division. Additionally, given the sample solutions in the study conducted by Russell $(2000$, p. 55), operation starts from the right in terms of the rule in the solutions with paper-pencil while it starts from the left to provide a holistic focus on number in mental calculation (Van de Walle, Karp \& Bay-Williams, 2012; Heirdsfield \& Cooper 2004).

Gülbağcl-Dede and Şengül (2016) stated that individuals with a developed number sense have advanced skills of reasoning and identifying whether the answer is reasonable and estimating the result of the mental calculation. In a study performed by Ulu (2017b) which identified the errors made by elementary students in non-routine problems, it was determined that a majority of the students could not see whether their answers were reasonable and could not estimate the approximate result. To explain the case with an example, many students answered the question "In a coop with chickens and rabbits, there are 12 heads and 30 feet. How many rabbits are there in the coop?" as "12×30 $=360 "$. It was expected from the students to conclude that there cannot be 360 rabbits in a coop with 12 heads even if they could not find the correct answer. However, it can be 
said that the students reached unreasonable answers as they could not reason their answer. Dowker (1992) stated that the causes of reasonable answers are highly related to number sense and argued that calculations would turn into irrelevant answers far away from the right answer for individuals with underdeveloped number sense when known rules are deviated from. Yet, the studies show that usage rate of number sense strategies are low while their rates of producing right answer are higher than the rulebased strategies (Alsawaie, 2011; Harç, 2010, Şengül \& Gülbağcı-Dede, 2012; Çekirdekçi, Şengül \& Doğan, 2016; Jordan, Glutting \& Ramineni, 2009, Mohamed \& Johnny, 2010; Çontay \& İymen, 2011).

Fluent calculation skills are required in order to provide continuance of strategies gained through the number sense during mental calculation process (Griffin, Case \& Siegler, 1994; Griffin \& Case 1997, NCTM, 2000). Fluency is described as the awareness of mental calculation strategies, identification of the strategy out of these strategies to facilitate the right answer rapidly and the crosscheck of the achieved answer with another strategy (Russell, 2000; Griffin, 2003; Carr, Taasoobshirazi, Stroud \& Royer, 2011; Walle, Karp \& Bay-Williams, 2010). In some of the definitions, calculation fluency is referred to be a subcomponent of number sense (Olkun, 2015; Burns, 2007; Markovits \& Sowder, 1994). Hiebert (1999) argues that understanding the relations between calculation fluency and number sense requires the examination of mathematical knowledge types (factual, procedural, conceptual).

Activities in recollection and memorization levels of mathematics are called factual knowledge; procedural knowledge refers to the solution achieved via strategies automatized as a result of constant repetitions and verified in each repetition; and conceptual knowledge is defined as the development of new strategies by integrating the first-encountered situations with existing knowledge in the memory (Schneider \& Stern, 2010; Anderson, 2010; Brynes \& Wasik 1991; Baroody, Feil \& Johnson, 2007). Gray and Tall (1994) explained the interrelationship of these knowledge types by the solution process of the $9+8$ operation. $A$ student trying to calculate it mentally can count on 9 with fingers to find the answer 17; as the student found the answer with the strategy of counting on what is available in the memory, he/she would end up using the procedural knowledge. However, the student would end up using the factual knowledge if he/she memorized this result and directly gave the answer 17 without counting fingers when the question was asked again. Thinking that the solution would take too long, the student might achieve the result 17 by adding 1 to 9 and subtracting 1 from 8 to transform the problem in to $10+7$ even though he/she knows the finger count strategy. Thus, he/she would developed a new strategy called "complementing to 10"; since attainment of the new strategy requires flexible use of numbers, it is associated with number sense and an example of conceptual knowledge. With the use of newly developed strategy in similar questions repetitively, the rate of calculation will increase, improving the procedural knowledge.

Hiebert (1999) emphasizes that every type of knowledge has a critical importance to mental calculation skills. For example, it may be regarded negatively when the student automatically gives the answer 17 as it refers to a memorized knowledge; however, it is expected from students to leave the physical calculation strategies behind and directly do a memory-based calculation in one-digit numbers for calculation fluency (Locuniak \& Jordan, 2008; Elia, Gagatsis \& Demetriou, 2007; Geary \& Hoard, 2005). Anderson (2010) underlined that as it would reduce the operation fluency to solve $7 \times 8$ by $8+8+8+8+8+8+8$ all the time, it is necessary to memorize the multiplication table. Previous studies showed that students with learning difficulty scored lower than normally-developing students in the mental calculation tests with time limitation (Jordon, Hanish, 2000; Hanish, Jordon, Kaplan \& Dick, 2001; Jordon, Hanish \& Kaplan, 2003; Anderson, 2010). In the longitudinal studies, it was observed that the lack of factual knowledge affects mathematical skills more negatively over years (Anderson, 2010; Jordon et al., 2003).

It has been determined that the question "How can I do it?" is related to procedural knowledge while the question "Why do I do these operations?" is associated with conceptual knowledge in mathematics (Schneider \& Stern, 2010; Anderson, 2010; Brynes \& Wasik 1991; Baroody, Feil \& Johnson, 2007). In the study conducted by Brynes and Wasik (1991), majority of the students gave the answer $3 / 6$ to the operation $1 / 2+2 / 4$ with unequal denominators which they had encountered for the first time, but some of the students found the answer 1 by reasoning it out as "two halves add up to one whole" although they did not know how to equalize denominators. This helps us to see that readily available rules (procedural knowledge) are not always enough and it is necessary to improve students' investigative thinking (conceptual knowledge). It has been observed that individuals who can think flexibly and tend to develop strategies in the first-encountered situations are better at mathematics; however, lack of procedural knowledge makes conceptual development difficult as it may cause individual to spend the energy required for thinking in calculations (Schneider \& Stern, 2010; Anderson, 2010; Brynes \& Wasik 1991; Baroody, Feil \& Johnson, 2007; Hallett, Nunes \& Bryant, 2010). In this context, it is possible to say that there is a dynamic interaction among types of mathematical knowledge and the development of one knowledge type requires other types (Anderson, 2010). Hiebert (1999) states that calculation fluency is related to factual and procedural knowledge while number sense to conceptual knowledge. Examining the relationships between the types of knowledge, even if we consider calculation fluency to be a subcomponent of number sense or that calculation fluency and number sense are different concepts, it may be said that number sense sometimes improves calculation fluency skills (Griffin, Case \& Siegler, 1994; Griffin \& Case 1997).

In Turkey, although there is no exact emphasis on the number sense in elementary school curricula, the emphasis is laid on developing the skills of mental calculation and mental estimation which are the components of number sense (MEB, 2005). According to Feigenson, Dehaene and Spelke (2004), mental calculation focuses on the exact result whereas mental estimation focuses on the approximate ones. We decide which strategy of mental calculation to use depending on the purpose of the calculation we will do. For instance, a cabin attendant working in a bus company that transport intercity passengers compares the number of ticketed passengers and the number of passengers present on the bus before the bus departs. Here, the attendant must perform an exact count because even if a single passenger was missing, it would mean trouble both for that passenger and the cabin attendant. Panhuizen (2001) states that approximate counting is utilized where exact result is not needed, possible or logical when calculating. When a father with TRY 300 in his pocket wants to buy his two kids two coats each priced at TRY 143, he does not need the exact result to calculate whether he can afford them. It is not possible for an individual driving to calculate at what time he/she will be at home with the exact counting approach because there are uncertainties such as traffic intensity and malfunction, etc. If a principal who is trying to figure out how many buses will be needed to take a 330-student group to trip by 60 -passenger buses per- 
forms an exact count, the result is 5.5 which is not realistic.

It is stated that how students can make conscious mental estimations is effective in the problem-solving process (Posamentier \& Krulik, 2016), mental estimation skill helps student estimate the result before starting to calculate the exact answer of a problem and question whether the achieved exact result is logical (Rogers \& Large, 2012). It has been also determined that estimation and control strategies make the highest contribution to the differentiation of students with high and low problem-solving achievement on the elementary school level (Ulu, 2017). MEB (2005) suggested six strategies to develop the mental estimation strategies (see Table 1) and stated that the strategies developed by students themselves, if any, should be given chance for usage in addition to these strategies. However, Artut and Aslan (2014) observed that some of the students could not perform estimation activities adequately due to lack of time and because the activities are not appropriate for students' levels. Previous studies have measured exact calculation skills rather than mental estimation skill (Griffin, Case \& Siegler, 1994; Griffin \& Case 1997; Russell, 2000; Griffin, 2003; Carr, Taasoobshirazi, Stroud \& Royer, 2011; Walle, Karp and Bay-Williams, 2010). In some of the studies (Şengül \& GülbağCl-Dede, 2014; Gülbağcl-Dede \& Şengül, 2016), estimation in mathematical operation was measured as a subcomponent of number sense. In this context, it is needed to identify the operational estimation skills which have a key role in everyday life and contribute to skills such as problem solving. Within this scope, answers to the following questions were searched for:

1. What are the strategies used by fourth-grade elementary students for making estimations in mathematical operations?

2. What is the (valid/invalid) result production level of the strategies used by fourth-grade elementary students in making operational estimations??

3. What is the distribution of the strategies used by fourth-grade elementary students in making operational estimation in terms of solution times?

\section{Methodology}

\section{Research Design}

Qualitative research is a type of research which utilizes data collection tools such as observation, interview, etc. and is carried out to explore phenomena and cases in a realistic manner within their environments (Creswell, 2013; Yıldırım \& Şimşek, 2016). Qualitative research is categorized in the groups of ethnographical, phenomenological, grounded theory, case study and action research (Yıldırım \& Şimşek, 2016). However, according to Merriam (2009), researchers do not always conduct a qualitative research study to examine a culture (ethnography), to reveal a phenomenon (phenomenology), to create a theory, to examine a given unit or a limited system (case study) or to identify and solve a problem (action research). Researchers sometimes conduct qualitative research in an interpretative approach as in this study; Merriam (2009) called the qualitative research studies based on the interpretative approach "basic qualitative research design". In such research studies, the basic point is to determine how the real world which affects individuals is interpreted by themselves (Merriam, 2009). In this study it is not aimed to either study a culture or create a theory as well as a given unit or limited system is not examined as it is in case studies. This study utilized the basic qualitative analysis design as it addresses the strategies used by the fourth-grade elementary students during operational estimation, to what degree these strategies lead to valid results and the time spent using the strategies in an interpretative manner.

\section{Participants}

This research has been conducted with 26 fourth-grade students attending an elementary state school. Mean age of the participant students is 9 . The research was carried out in the fall term of 2016/2017 educational year. The convenience sampling method was used for selecting the participants. Convenience sampling method suggests that the sample is selected from easily applicable units due to limitations of condition, time, money, and workforce (Merriam, 2009; Yıldırım \& Şimşek, 2016). Since it might take 40 minutes to interview a student in the pilot application of the study, it was thought that it would be difficult to designate the time suitable both for the researchers and the interviewees in the data collection process. Thus, the fourth-grade students whose teacher were one of the researchers were selected for the sample to overcome the time problem. Indeed, the fact that the data collection process took 12 hours and 33 minutes in total proved the decision to be accurate. Official permission of the parents of the students in the sample was received, and the students participated in the study voluntarily. The administrators of the school were informed of the research. In its elementary school mathematics curriculum, MEB (2005) implicitly recommends providing students with skills of doing operation without using paper-pencil regarding the mental mathematical four operation skills on the fourthgrade level. The teacher of the sample classroom uses the activities of operational estimation within the framework recommended by MEB (2005).

\section{Data Collection and Analysis}

The Elementary School Mathematics Curriculum aims to develop two types of estimation skills which are in operation and assessment. The research focuses only on developing the operational estimation skills. Accordingly, a 20 -question scale consisting of 5 questions from each of the addition, subtraction, multiplication and division operations was developed in order to determine operational estimation strategies used by the students. When developing the scale, limitations in the operational estimation activities specified in the curriculum that is provided by MEB (2005) were considered. Therefore, the template scale was prepared based on the following outcomes within the scope of operational estimation activities in the elementary school mathematics curriculum: "Student can estimate the sum of no more than four-digit natural numbers. Student can estimate the difference of two no more than three-digit natural numbers. Student can estimate the multiplication of two no more than two-digit natural numbers. Student can estimate the result of a division." The scale created within the framework of these outcomes in question was submitted for the opinions of three mathematics teaching experts and three elementary teachers, and the template scale was prepared. To determine convenience of the template scale for student levels, duration of interviews, and the problems that might arise during interviews, 6 fourth-grade elementary students were interviewed. The students were selected from a different fourth-grade class of the same school for the pilot implementation. The data recorded in the pilot implementation were reviewed by the three mathematics teaching experts again to finalize the scale.

The data were collected in English and Religious Culture and Ethics courses as students' teacher were on leave. The 20-question scale form was applied to 26 participant students with the semi-structured interview technique. In this technique, although the researcher has prepared the 
Table 1. Thematic framework of the research

\begin{tabular}{|c|c|}
\hline Strategies & Description \\
\hline Rounding & $\begin{array}{l}\text { It is the estimation of the result by rounding (up or down) the numbers to appropriate } \\
\text { values in the operation. When estimating the result of } 159+237,237 \text { can be rounded } \\
\text { up to } 250 \text { and then } 159 \text { down to } 150 \text { so that one can estimate } 150+250=400 \text {. }\end{array}$ \\
\hline Grouping & $\begin{array}{l}\text { The result is estimated by grouping the numbers if they are close to a certain value. } \\
\text { All of the numbers in } 423+397+402+384 \text { are close to } 400 \text {. The result is estimated to be } \\
1600 \text { by multiplying } 400 \text { by } 4 \text {. }\end{array}$ \\
\hline Using the front-end orders & $\begin{array}{l}\text { It is the estimation of result by adding the leftmost and rightmost digits. When esti- } \\
\text { mating the result of } 1900+3050+609 \text {, the result is estimated to be } 1000+3000+600= \\
4600 \text { by adding the leftmost digit values of the given numbers. }\end{array}$ \\
\hline Using matched numbers & $\begin{array}{l}\text { It is the estimation of result by grouping the numbers which are the easiest to be } \\
\text { calculated mentally. In } 32+48+54+18+69 \text {, the result of } 32+69 \text { is estimated to be } 100 \text {; } \\
\text { the result of } 48+54 \text { is estimated to be } 100 \text {. Adding } 18 \text { to the calculation, the result is } \\
\text { estimated to be } 218 \text {. }\end{array}$ \\
\hline Distribution & $\begin{array}{l}\text { When estimating the result of } 76 \times 89 \text {, the operation is transformed into }(76 \times 100)- \\
(76 \times 10)=7600-760 \text { and the result is estimated to be } 6800 \text {. }\end{array}$ \\
\hline Adjusting-rearranging & $\begin{array}{l}\text { This strategy is used for rendering the estimate result more appropriate for and clos- } \\
\text { er to the exact result. When using this strategy to solve } 2124 \times 13 \text { : }\end{array}$ \\
\hline Algorithmic calculation & $\begin{array}{l}\text { If } 2124 \times 13=(2100+24) \times(10+3) \\
2100 \times 10=21000, \text { then the error margin in this operation is }(2100 \times 3)+(24 \times 13) \text {. } \\
\text { Rounding } 2100 \rightarrow 2000 \text {, then } 2000 \times 3=6000 \\
21000+6000=27000 \\
\text { Rounding } 24 \rightarrow 30 ; 13 \quad 10 \text {, then } 30 \times 10=300 \\
27000+300=27300\end{array}$ \\
\hline Algorithmic calculation & $\begin{array}{l}\text { In this strategy, students do mental calculation as if they calculated with paper-pen- } \\
\text { cil. In } 32+48+92=\text {, they first add the numbers in the unit's digit and find the result } \\
2+8+2=12 \text {. Then, they keep the number } 2 \text { in the units digit of their result in mind and } \\
\text { carry the tens digit as } 1 \text {. Next, they add the tens digits } 3+4+9=16 \text { and add the carry } 1 \\
\text { to find } 17 \text {. Attaching the number } 2 \text { in the units digit, they estimate the result to be } 172 \text {. }\end{array}$ \\
\hline
\end{tabular}

questions before starting the interview, it can be also ensured that answers are detailed with different questions depending on the direction of the interview (Yıldırım \& Şimşek, 2016, Creswell, 2013). Before the interview, the students had been guided with the instructions "I want you to solve the problems on the paper in your mind. You do not need to find the exact result; just try to find the closest result." During the interview, where it could not be determined how the students did their operational estimations, they were asked "Why did you do this operation? Do you explain how you found this result? Can you detail how you did the operation?" to explore the strategies they used for the solution. Before the semi-structured interviews, the 20-question scale was handed to the students, and they were asked to solve the problems in the form without using paper-pencil, achieve results as close as possible to the exact result and solve the problems thinking out loud. Other students except for the interviewee were not allowed in the room during the interviews so that the possible distractions for the interviewees can be eliminated and other interviewees could not see the questions. The students were individually informed of the research before the application and that it would not affect their mathematics grade anyway. The interviews were videotaped.

In the next stage of the research, 12 hours 33 minutes of video records in total were analysed. The research data were analysed through content analysis (Elo \& Kyngäs, 2008; Vaismoradi, Turunen \& Bondas, 2013). Qualitative content analysis can be defined as the procedure of classifying and interpreting the content of written texts via encoding and creating themes or patterns systematically (Hsieh \& Shannon, 2005). In this framework, the following steps were followed when analysing the research data: (1) forming the framework of themes, (2) doing the first thematization, (3) rearranging the theme framework, (4) performing the main analysis, (5) coding reliability, and (6) writing down and interpreting the findings. In content analysis, researcher may use a coding system available in the literature. If there is no appropriate coding system in the literature, the researcher can develop a coding system or add possible codes to an available coding system to obtain the required data (Smith, 2000). Accordingly, the rounding, grouping, using the front-end orders, using matched numbers, distribution, adjusting-rearranging strategies recommended for operational estimation by MEB (2005) formed the first thematic framework; however, the themes developed by MEB (2005) were found as insufficient in categorizing the themes when the interviews with the students were taken into consideration. In this context, once adding a strategy recommended by Van de Walle et al. (2012), it was observed that all solutions could be categorized, and the algorithmic calculation strategy was further added to form the thematic framework of the research. The thematic framework is given in Table 1.

After determining the themes in Table 1, the video record which involved 520 solutions covering the estimations of 26 students for 20 questions was reviewed. It is recommended that multiple experts are consulted when thematising the data to increase the validity and reliability of thematic classification in qualitative research (Yıldırım \& Şimşek, 2016, Miles \& Huberman, 2015; Creswell, 2013). In this context, mutual opinions of three mathematics teaching experts were taken as basis to ensure the reliability of the thematisation of solutions. For thematisation, the estimations made by the students depending on their strategies were classified as being valid or invalid. For instance, given that a student estimating the result of $152+358+429=$ rounded 152 down to 150,358 to 350 , and 
429 to 400 , then this estimation using the rounding strategy was considered valid if the student estimated the result to be $150+350+400=900$. However, given that a student used the same strategy to estimate $150+350+400$ to be 1200 , this result was classified as invalid as it was unrelated with the exact result. When deciding the valid or invalid estimations, whether the students applied the strategy of their preference correctly was also considered. A student using the rounding strategy for $179+289$ should round the numbers up to the nearest hundred. So, result achieved by rounding down to $100+200$ would be invalid as the student did not rounded up to the nearest hundred. On the other hand, if it was understood from the student's explanation that he/she estimated the result by using the front-end orders, $100+200$ would be accepted to be valid because the student applied the strategy correctly as the first digit is 1 in 179 and 2 in 279. The experts discussed the solution and reached a consensus where they could not agree on the strategies or valid/invalid results, and there were no disagreed solutions.

According to the thematisation performed for the first research question, the solutions categorized into strategies were included in a frequency analysis by the operations of addition, subtraction, multiplication and division, and the usage percentage of the strategy was found by dividing the number of strategy being used by the number of solutions in an operation. General usage rates of the strategies were also determined in the research. Since there were 26 students in the sample and 5 questions were asked for each operation, usage rate for each solution was calculated by dividing the number of solutions 130 as there were $26 \times 5=130$ solutions; general usage rate was calculated by dividing the number by 520 as there were $26 \times 20=520$ solutions. For instance, assuming that the rounding strategy was used for 23 times in addition, usage rate of this strategy in addition would be $23 / 130=17.70$. If the same strategy was used for 76 times in all four operations, the general usage rate would be $76 / 520=14.62$.

For the second research question, the rates of strategies leading to valid/invalid result were calculated. Within this scope, a strategy's rate of producing valid estimation was calculated by dividing the number of valid estimations by the number of the strategies used for the solution and the rate of producing invalid estimation by dividing the number of invalid estimations by the number of the strategies used for the solution in total. For instance, if the rounding strategy was used for 23 times in addition and 16 of them were valid and 7 of them were invalid, this strategy's rate of valid estimation in addition would be $16 / 23=69.56$, and the rate of invalid estimation would be $7 / 23=30.44$. By this means, strategies' percentages of producing valid/invalid solution were obtained both for each solution and the study in general.

The fluency of strategies in estimation period was analysed for the third research question. Accordingly, the duration that each strategy took to produce a valid estimation was added to each other, and the sum was divided by the number of total valid solutions produced by each strategy to calculate the mean valid estimation time. For example, given that there were 16 valid estimations made with the rounding strategy in addition and total time that these estimations took was 980 seconds, then the fluency rate of this strategy in the valid estimations would be 980 seconds/16 solutions $=61$ seconds .

\section{Findings}

In this section, the findings obtained in the research are included. Accordingly, answer to the first research question "What are the strategies used by fourth-grade elementary students during mathematical operational estimation?" was searched for, and the findings are presented in Table 2.

According to Table 2, the fourth-grade elementary students majorly used the algorithmic calculation technique during operational estimation at $74.04 \%$ (383). It was observed that the fourth-grade elementary students used the strategies of adjusting-rearranging at $10.00 \%$ (52), rounding at $4.81 \%(25)$, using matched numbers at $2.69 \%$ (14) which are the strategies recommended by MEB (2005) for the development of operational estimation skills while they did not prefer to use the strategies of using the frondend orders, grouping and distribution. Considering the results on the basis of operations, the most commonly used strategy in all of the estimations in four operations was algorithmic calculation strategy at the rates varying between $62.31 \%$ (81) and $80.00 \%$ (104). In addition, the strategies of adjusting-rearranging (20.77\%), using matched numbers $(10.77 \%)$, and rounding $(3.85 \%)$ recommended by MEB (2005) were used respectively. The strategies recommended by MEB (2005) that were used in subtraction were rounding $(6.92 \%)$ and adjusting-rearranging (6.92\%) respectively, and adjusting- rearranging (8.46\%) and rounding $(4.62 \%)$ in multiplication. In division, rounding and adjusting-rearranging strategies were used at the same rate (3.85\%). This finding indicates that a great majority of the students solved the operations mentally as if they were calculating with paper-pencil when estimating the result in four operations and preferred the strategies recommended by MEB (2005) less.

Table 2. Percentage-frequency table regarding the distribution of strategies used by the fourth-grade students during operational estimation

\begin{tabular}{|c|c|c|c|c|c|c|c|c|c|c|}
\hline & $f$ & $\%$ & $f$ & $\%$ & $f$ & $\%$ & $f$ & $\%$ & $f$ & $\%$ \\
\hline Rounding & 5 & 3.85 & 9 & 6.92 & 6 & 4.62 & 5 & 3.85 & 25 & 4.81 \\
\hline Grouping & - & - & - & - & - & - & - & - & - & - \\
\hline Using front-end orders & - & - & - & - & - & - & - & - & - & - \\
\hline Using matched numbers & 14 & 10.77 & - & - & - & - & - & - & 14 & 2.69 \\
\hline Distribution & - & - & - & - & - & - & - & - & - & - \\
\hline Adjusting-rearranging & 27 & 20.77 & 9 & 6.92 & 11 & 8.46 & 5 & 3.85 & 52 & 10.00 \\
\hline $\begin{array}{l}\text { Algorithmic } \\
\text { calculation }\end{array}$ & 81 & 62.31 & 104 & 80.00 & 106 & 81.54 & 94 & 72.30 & 385 & 74.04 \\
\hline Blank & 3 & 2.31 & 8 & 6.15 & 7 & 5.38 & 26 & 20.00 & 44 & 8.46 \\
\hline Total & 130 & 100 & 130 & 100 & 130 & 100 & 130 & 100 & 520 & 100 \\
\hline
\end{tabular}


Table 3. Distribution of the valid/invalid results reached by the fourth-grade students in terms of the strategies during operational estimation

\begin{tabular}{|c|c|c|c|c|c|c|c|c|c|c|c|}
\hline \multirow{2}{*}{ Strategies } & \multirow[b]{2}{*}{ Estimation } & \multicolumn{2}{|c|}{ Addition } & \multicolumn{2}{|c|}{ Subtraction } & \multicolumn{2}{|c|}{ Multiplication } & \multicolumn{2}{|c|}{ Division } & \multicolumn{2}{|c|}{ Total } \\
\hline & & $f$ & $\%$ & $f$ & $\%$ & $f$ & $\%$ & $f$ & $\%$ & $f$ & $\%$ \\
\hline \multirow{3}{*}{ Rounding } & Valid & 5 & 100 & 9 & 100 & 6 & 100 & 5 & 100 & 25 & 100 \\
\hline & Invalid & - & - & - & - & - & - & - & - & - & - \\
\hline & Total & 5 & 100 & 9 & 100 & 6 & 100 & 5 & 100 & 25 & 100 \\
\hline \multirow{3}{*}{$\begin{array}{l}\text { Using matched } \\
\text { numbers }\end{array}$} & Valid & 12 & 85.71 & - & - & - & - & - & - & 12 & 85.71 \\
\hline & Invalid & 2 & 14.29 & - & - & - & - & - & - & 2 & 14.29 \\
\hline & Total & 14 & 100 & - & - & - & - & - & - & 14 & 100 \\
\hline \multirow{3}{*}{$\begin{array}{l}\text { Adjusting-rear- } \\
\text { ranging }\end{array}$} & Valid & 22 & 81.48 & 9 & 100 & 7 & 63.64 & 5 & 100 & 43 & 82.69 \\
\hline & Invalid & 5 & 18.52 & - & - & 4 & 36.36 & - & - & 9 & 17.31 \\
\hline & Total & 27 & 100 & 9 & 100 & 11 & 100 & 5 & 100 & 52 & 100 \\
\hline \multirow{3}{*}{$\begin{array}{l}\text { Algorithmic } \\
\text { calculation }\end{array}$} & Valid & 50 & 61.73 & 91 & 87.50 & 63 & 59.43 & 55 & 58.51 & 254 & 66.32 \\
\hline & Invalid & 31 & 38.27 & 13 & 12.50 & 43 & 40.57 & 39 & 41.49 & 129 & 33.68 \\
\hline & Total & 81 & 100 & 104 & 100 & 106 & 100 & 94 & 100 & 383 & 100 \\
\hline
\end{tabular}

Following the solution of the first research question, the answer to the second research question "What is the distribution of strategies used by fourth-grade elementary students during operational estimation by solution times?" was searched for, and the findings are illustrated in Table 3.

It is understood from Table 3 that rounding was the strategy with which the fourth-grade students were the most effective in producing valid estimations at $100 \%$, and it was followed by the strategy of using matched numbers at $85.71 \%$ and the strategy of adjusting-rearranging at $82.69 \%$. It was found that algorithmic calculation which was the most frequently used strategy by the fourth-grade students during operational estimation could produce valid estimations at $66.32 \%$. In the light of these findings, algorithmic calculation's rate of producing valid estimations was 35\% lower than rounding, 22\% lower than using matched numbers, and $16 \%$ lower than adjusting-rearranging. It can be accordingly argued that the operational estimation strategies recommended by MEB (2005) were more effective than the mental algorithmic calculation like calculating with paper-pencil. Next section of the research addresses the estimation strategies used by the fourthgrade elementary students in each of the four operations in detail.

Addition. When estimating the result of addition, the most used strategy was found to be algorithmic calculation at $62.31 \%$, and $61.73 \%$ (50) of the estimations were valid. The following is a student interview regarding a valid estimation using the algorithmic calculation strategy:

Operation: $74+36+27+63=$ ?

Student 4 (54): I added 3 to 7, it is 10; I added 6, it is 16; 4 more add up to 20. I wrote down the zero and carried 3; I added 6 to 2, it is 8 ; I added 3 to it to find $11 ; 11$ plus 7 is $18 ; 2$ more, it is 20. The result is 200. Researcher (R): Why did you add 2 to 18 ?

S4: Because I carried 2.

Investigating the interview, the student started to estimate the result of addition from the units digit, kept the unit digit of the obtained result and the carry in mind and then added the tens digits respectively and finally added the last carry to find 200 . $38.27 \%$ of the estimations using the al- gorithmic calculation strategy in addition were invalid. The following is a student interview regarding an invalid estimation using the algorithmic calculation strategy:

Operation: $139+156+105=$ ?

S5: First, we add 9 to 6. Adding 5 to the sum, we write 0 in the units digit and carry 2. Then we add 3 to 5 , it is 8; we carried 2, it adds up to 10; so, we write 0 again. Then we get to the hundreds digit. 1 plus 1 is 2 , then we add it to 1. The result is 300 .

$R$ : Why did you add another 1 after adding 1 to 1 ?

S5: To add the hundreds digit of 139.

It was observed in the interview that the student added the carry 2 which he/she reached by adding the units digits of the numbers to the tens digit, carried the 1 by adding the tens digits but forgot to add it to the hundreds digit. When estimating the result of addition, the second most commonly used strategy was found to be adjusting-rearranging at $20.77 \%$, and $81.48 \%$ (22) of the estimations were valid. The following is a student interview regarding a valid estimation using the adjusting-rearranging strategy:

Operation: $139+156+105=$ ?

S1: 100 plus 100 plus 100 is 300.300 plus 40 is 340; adding 55 more, it is 395. 395 plus 5 is 400 .

R: How did you do it? How did you find 40 and 55 ?

S1: I added 1 to 39 and subtracted 1 from 56.

$R$ : Why did you do such thing?

S4: Because it was easy to add.

Investigating the interview, starting from the 100s, the student constantly adjusted the solution and achieved the exact result in the end. $18.52 \%$ (5) of the estimations using the adjusting-rearranging strategy in addition were invalid. The following is a student interview regarding an invalid estimation using the adjusting-rearranging strategy:

Operation: $139+156+105=$ ?

S: 100 plus 100 is 200; 100 more, it is 300.30 plus 50 is 80; 80 plus 50 is 130 .

R: Go on.

S: It is 430 so far. 9 plus 6 is $15 ; 15$ plus 5 is 20 . It is 450 in total.

It was observed in the interview that the student did the 
solution rightwards as in the mental calculations, started to estimate from the hundreds and then added the tens and finally the units. Yet, the student made a mistake because of adding the 5 in 105 two times both in the tens and units digits. When estimating the result of addition, the third most commonly used strategy was found to be using matched numbers at $10.77 \%$, and $85.71 \%(12)$ of the estimations were valid. The following is a student interview regarding a valid estimation using the strategy of using matched numbers:

\section{Operation: $139+161+125+175=$ ?}

S6: $139+161+125+175=$ ? It is 300 when we add 125 to 175 .

R: Go on.

S6: It is also 300 when we add 139 to 161.

R: How 300 ?

S6: 61 plus 39 is 100; 100 plus 100 is 200. There

was another 100, it adds up to 300.

$R$ : Yes, continue.

S6: We had a 300 above; 300 plus 300 is 600.

According to the interview, the student matched and added 125 to 175,139 with 161 to reach 300. 14.29\% (1) of the estimations using the strategy of using matched numbers in addition were invalid. The following is a student interview regarding an invalid estimation using the strategy of using matched numbers:

Operation: $48+76+53+24=$ ?

S10: 48 plus 53 is 1000

$R$ : How did you find it?

S: I added in my mind.

R: How, could you tell me a little bit? Why did you add 48 to 53 in the first place?

S: Because they add up to 1000.

R: Go on.

S: 76 plus 24 is 1000 . 1000 plus 1000 is 2000, but roughly.

It was observed in the interview that the student matched and added 48 to 53 and 76 to 24 and found the results of both additions not approximately 100 but 1000 . The least commonly used strategy in addition was found to be rounding at $3.87 \%$ (5). $80 \%$ (4) of these estimations were valid. The following is a student interview regarding a valid estimation using the rounding strategy:

Operation: $74+36+27+63=$ ?

S4: I will tell the estimate result; I added 60 to 30. What is it? 90. I added 90 to 40, it is 130. And I added 130 to 70 . It is 200. Guessingly.

R: Why did you add 90 to 40 ?

S: Because you said guessingly, I thought of 36 as if it was 40.

$R$ : Then, you thought of 27 as if it was 30 ?

S: Yes. 74 as if 70,63 as if 60 , for example.

The interview showed that the student did the addition by rounding the estimate numbers up to the nearest ten.

Subtraction. When estimating the result of subtraction, the most commonly used strategy was found to be algorithmic calculation at $80 \%$, and $87.50 \%$ (91) of the estimations were valid. The following is a student interview regarding a valid estimation using the algorithmic calculation strategy:

Operation: $403-45=$ ?

s10: 358
R: How did you do it?

S10: You cannot subtract 5 from 3; I would borrow a ten from the tens, but there was not any. I borrowed 1 from the hundreds, then 0 became 10. I borrow 1 from 10 and turned 3 into 13.1 made 0 into 9 and 4 into 3.13 minus 5 is 8,9 minus 4 is 5 ; there is nothing below 3, I copied it. It is 358 .

According to the interview, the student did the solution as if he/she was calculating with paper-pencil. $12.50 \%$ (13) of the estimations using the algorithmic calculation strategy in subtraction were invalid. The following is a student interview regarding an invalid estimation using the algorithmic calculation strategy:

Operation: $403-45=$ ?

S8: 53

R: How did you do it?

S8: First, I placed the 45 here in my mind as in the column subtraction. I brought the 3 down.

R: Wait a second, where did you put the 45? Exactly? S8: Below the 40. You cannot subtract 5 from it; I borrowed from the tens digit and 0 became 10. 4 and 3 remained. I subtracted. I wrote 5 because of 10 minus 5. I brought the 3 down. 4 minus 4 is zero. I found 53 .

It was observed in the interview that the student shifted the tens digit of 45 to the hundreds digit, its units digit to the tens digit. When estimating the result of subtraction, the rounding strategy was found to be used at $6.92 \%(9)$, and $100 \%$ (9) of the estimations were valid. The following is a student interview regarding a valid estimation using the rounding strategy:

\section{Operation: $83-29=$ ?}

S2:50, but roughly.

$R$ : How did you find it?

S2: 83 becomes 80,29 becomes 30. 80 minus 30 equals to 50 .

In this interview, the student rounded the numbers to the nearest ten to do the subtraction. When estimating the result of subtraction, it was observed that the adjusting-rearranging strategy was used at $6.92 \%$ (9), and $100 \%$ (9) of the estimations were valid. The following is a student interview regarding a valid estimation using the adjusting-rearranging strategy:

\section{Operation: $213-139=$ ?}

S1: 200 minus 100 equals to 100. 100 minus 40 equals to 60. $R$ : How did you find the 40 ?

S1: I took 39 as if it was 40. R: Go on.

S1: 60 plus 13 is 73 .

R: Where did the 13 come from? It was in the 213. I did not calculate it.

It was observed in the interview that the student reached the result with 3 operations, started to subtract the numbers from left and each operation made it closer to the exact result.

Multiplication. When estimating the result of multiplication, the most commonly used strategy was found to be algorithmic calculation at $81.54 \%(106)$, and $53.43 \%$ (55) of the estimations were valid. The following is a student interview regarding a valid estimation using the algorithmic calculation strategy:

Operation: $213 \times 4=$ ? 
S1: 3 times 4 is 12; we write 12 down. 1 times 4 is 4 we add the 1 of the 12, which makes it 5.4 times 2 is 8; we write 52 down next to 8 . It is 852 .

The student in the interview did the operations starting from the right and used the phrase "we write" when doing the mental calculation. It was observed that $40.57 \%$ (43) of the estimations using the algorithmic calculation strategy in multiplication were invalid. The following is a student in terview regarding an invalid estimation using this strategy:

Operation: $213 \times 4=$ ?

S23: 4 times 3 is 16; we carry 1 and write 6 down. 4 times 1 is 5, 4 times 2 is 12; now that we found 12, we multiply 4 by 4 . We add 16 and 20. And we add 12 to 20 . It is 32 .

It can be understood from the interview that the student made mistakes due to lack of factual knowledge and found the results of some of the operations $(4 \times 3=16$ and $4 \times 2=12)$ incorrect and also made errors regarding the concept of digit value. When estimating the result of multiplication, the second most commonly used strategy was found to be adjusting-rearranging at $8.46 \%(11)$, and $63.64 \%$ (55) of the estimations were valid. The following is a student interview regarding a valid estimation using the adjusting-rearranging strategy:

\section{Operation: $324 \times 3=$ ?}

\section{S21: 972}

R: How did you find it?

S21: 3 times 3 is 9; then 3 pieces of 300 are 900. 3 pieces of 20 are 60.3 pieces of 4 are 12.900 plus 60 equals to 960.12 more, it is 972 .

It was observed in the interview that the student did the solution in three stages starting from the left and got closer to the right answer in each operation to achieve the exact result. $36.36 \%(43)$ of the estimations using the adjusting-rearranging strategy in multiplication were found to be invalid. The following is a student interview regarding an invalid estimation using this strategy:

Operation: $12 \times 15=$ ?

S: 10 times 10 is 100.12 times 10 is 120 . It is 220.2 times 15 is 30, and the result is 250 .

According to the interview, the student started the solution from left but used the 1 in the 12 twice and did not include the 1 in the 12 and the 5 in the 15 in the operation. The least commonly used strategy in multiplication was rounding at $4.62 \%(6)$ and $100 \%$ (6) of the estimations were valid. The following is a student interview regarding a valid estimation using the rounding strategy:

Operation: $35 \times 23=$ ?

S5: Assume 23 to be 20. We multiply 35 and 20. It may be 700 .

R: How did you multiply 35 and 20.

S5: 35 times 2 is 70; we add 0 next to it.
It was observed in the interview that the student kept the 35 fixed as he/she did not think he/she would have difficulty in multiplying it but rounded the 23 down to 20 as he/she thought he/she would have difficulty in multiplying the 23.

Division. When estimating the result of division, the most commonly used strategy was found to be algorithmic calculation at $72.30 \%$ (94), and $58.51 \%$ (55) of the estimations were valid. The following is a student interview regarding a valid estimation using the algorithmic calculation strategy:

Operation: 634:9=?

S13: There is no 9 in 6; in 63... (does rhythmic count with fingers.) ...there are seven 9s; 7 times 9 is 63. We subtract 63 from 63, it is 0 . There is no 9 in 4, so we add a 0 next to 7 , it is 70 .

According to the interview, the student calculated the problem mentally as if he/she were calculating with paper-pencil. It was observed that $41.49 \%$ (43) of the estimations using the algorithmic calculation strategy in division were invalid. The following is a student interview regarding an invalid estimation using this strategy:

Operation: 625:6=?

S22: There is one 6 in 6.6 minus 6 is 0 ; as there is no 6 in 2, we look for 6 in 25. 6, 12, 18, 24; we subtract because there is 4.25 minus 24 is 1 , the result is 14 .

In the interview, the student said, "...as there is no 6 in 2 , we look for 6 in $25^{\prime \prime}$ because he/she calculated on the rule basis but did not use the rule of adding 0 in quotient. When estimating the result of division, the adjusting-rearranging strategy was found to be used at $3.85 \%(5)$, and $100 \%$ (3) of the estimations were valid. The following is a student interview regarding a valid estimation using the adjusting-rearranging strategy:

Operation: 625:6=?

S6: 625 is divided by 6, (pauses for 50 seconds) it is 104.

R: How did you do it?

S6: It is a hundred when you divide 600 by 6. I divided 25 by 6 to find 4 . And I added 100 and 4 ?

It was observed in the interview that the student did the solution in two stages, first divided 600 by 6 and then 25 by 6 to rearrange the result and finally added 100 and 4 which were the results of these two operations. When estimating the result of division, the rounding strategy was found to be used at $3.85 \%(5)$, and $100 \%$ (5) of the estimations were valid. The following is a student interview regarding a valid estimation using the rounding strategy:

Operation: $296: 3=$ ?

S: Thinking of 296 as 300, if 300 is divided by 3, it is 100 .

In this interview, the student rounded the number to the

Table 4. Distribution of strategies used by fourth-grade elementary students during operational estimation by valid solution times

\begin{tabular}{lccccc}
\hline Strategies & Addition & Subtraction & Multiplication & Division & Total \\
\hline Rounding & 60 & 41 & 35 & 43 & 44 \\
\hline Using matched numbers & 50 & - & - & - & 50 \\
\hline Adjusting-rearranging & 58 & 47 & 43 & 67 & 54 \\
\hline Algorithmic calculation & 86 & 71 & 76 & 88 & 81 \\
\hline
\end{tabular}


nearest hundred to find the result. Next, the answer to the third research question "What is the distribution of strategies used by fourth-grade elementary students during operational estimation by solution times?" was searched for. The findings are presented in Table 4.

According to Table 4, algorithmic calculation strategy had the longest solution time with 81 seconds for valid estimations, which was followed by adjusting-rearranging with 54 seconds, using matched number with 50 seconds and rounding strategy with 44 seconds. Furthermore, algorithmic calculation strategy had the longest solution time in each operation. In this context, it can be argued that rulebased algorithmic calculation strategy decreases the fluency (accuracy + speed) of mental calculation skills in terms of rate of producing valid result and time allocated for estimation.

\section{Discussion, Conclusion and Recommendations}

It is stated that we mostly solve the problems which require calculation in our daily lives mentally (Reys, Reys, Nohda \& Emori, 1995, Yazgan, Bintaş \& Altun, 2002, Gülbağcı-Dede \& Şengül, 2016). Feigenson et al. (2004) state that mental calculation is divided into two groups of exact counting and approximate counting also called operational estimation. Panhuizen (2001) stated that we make operational estimation in making calculations in our daily life when the exact result is not needed, not possible or logical. Mental estimation is regarded significant to estimate the result before calculating the exact result and question whether the exact result is logical (Rogers \& Large, 2012). MEB (2005) lays a strong emphasis on the development of mental operational estimation strategies from elementary school ages. In this context, this research aimed to identify the strategies used by the fourth-grade elementary students when mentally estimating the result of four basic mathematical operations and explore the effects of those strategies on operational fluency (accuracy + speed).

The research results showed that the fourth-grade students preferred rule-based (algorithmic calculation) strategies when making operational estimation in a majority (74.04\%) of the solutions. The studies indicate that students prefer rule-based strategies in exact result-oriented mental calculations, too (Alsawaie, 2011; Harç, 2010; Şengül \& Gülbağcı-Dede, 2012; Çekirdekçi, Şengül \& Doğan, 2016; Jordan, Glutting \& Ramineni, 2009; Mohamed \& Johnny, 2010; Çontay \& lymen, 2011). It can be accordingly argued that the students cannot get over the rules when doing either mental approximate or exact counting. Several studies show that rule-based strategies obstruct the development of advanced conceptual skills such as questioning, reasoning and problem solving even if they lead to the right answer (Dowker, 2005; Baki \& Kartal; 2004, Anderson, 2010; Brynes \& Wasik 1991, Ulu, 2017). Current educational systems regard mathematics as a system that assists flexible thinking and strategic development rather than a discipline in which strict rules are applied (Chinese National Mathematics Curriculum, 2001; National Council of Teachers of Mathematics, 2000; Australian Education Council, 1991; MEB, 2005). However, most of the teachers who are expected to bring flexible and strategic thinking skills to students (Gülbağcı-Dede \& Şengül, 2016; Yang et al, 2009) and pre-service teachers who are expected to do so when they start their career (Kayhan-Altay \& Umay, 2011; Şengül, 2013; Gülbağcı-Dede \&Şengül,2016; Artut, 2015; Er $\&$ Artut, 2016) cannot get over the rule-based strategies.

It was found in the research that the elementary school fourth-grade students preferred the strategies of adjusting-rearranging $(10 \%)$, rounding $(4.81 \%)$ and using matched numbers (2.69\%) recommended by MEB (2005) but did not prefer strategies of using front-end orders and distribution. Based on these results, it can be said that the usage rate of strategies recommended by MEB (2005) were very low (17.5\%). In various studies on mental calculation, strategies other than rule-based solutions are called number sense-based strategies (Alsawaie, 2011; Harç, 2010, Şengül \& Gülbağcı-Dede, 2012; Çekirdekçi, Şengül \& Doğan, 2016; Jordan, Glutting \& Ramineni, 2009, Mohamed \& Johnny, 2010; Çontay \& lymen, 2011). In those studies, the usage rates of number sense strategies were found to be lower as in this study. The study conducted by Russell (2000) shows that elementary students can orientate towards number sense strategies from rule-based strategies with a little support. It is observed in the literature that students can use number sense strategies before starting the elementary school as they do not know the rule-based strategies (Olkun et al., 2015; Griffin et al., 1994; Griffin \& Case 1997; Altun, et al., 2001). It is teachers' duty to add new number sense strategies to the ones existing in preschool and prevent number senses strategies from remaining in the background with the learning of rule-based strategies. Accordingly, the Australian Education Council (1991) decided that four operations are first to be taught to students through mental calculation skills and then rule-based algorithms are put into play to support flexible thinking and strategic development. The studies also indicate that individuals who can use the number sense strategies have higher mathematical achievement (Harç, 2010; Şengül \& Gülbağcı, 2012; Yang, Li \& Lin, 2008; Çekirdekçi, Şengül \& Doğan, 2016).

It is stated that the individuals with number sense have mental calculation fluency, and the foremost component of fluency is accuracy (Russell, 2000; Griffin, 2003; Carr, Taasoobshirazi, Stroud \& Royer, 2011; Walle, Karp \& Bay-Williams, 2010). The research results showed that rule-based algorithmic calculation strategy's rate of producing valid solution (66.32\%) was lower than the rates of rounding (100\%), using matched numbers $(85.71 \%)$ and adjusting-rearranging (82.69\%). The research finding that rule-based strategies' rate of leading to the right answer is lower than the number sense strategies coincides with the literature (Alsawaie, 2011; Harç, 2010, Şengül \& Gülbağcı-Dede, 2012; Çekirdekçi, Şengül \& Doğan, 2016; Jordan, Glutting \& Ramineni, 2009, Mohamed \& Johnny, 2010; Çontay \& Iymen, 2011). Dowker (1992) stated that a tiny deviation from rules in rule-based solutions would turn into solutions that are irrelevant to the right answer. The findings obtained in the interviews are consistent with Dowker's argument; it was seen in the research that the main reason for the invalid estimations using the algorithmic calculation strategy was that students made mistakes in the four operation-specific rules such as failing to the digits accurately, forgetting the carry, breaking tens digit down and adding 0 in quotient. It has been determined that individuals who apply the rules in mathematics without questioning them use much of the factual and procedural knowledge while those who question how rules are formed, can develop strategies and use them flexibly use their conceptual knowledge more frequently (Schneider \& Stern, 2010; Anderson, 2010; Brynes \& Wasik 1991; Baroody, Feil \& Johnson, 2007). The fact that a majority of the elementary students make solutions using rule-based strategies and the rate of the valid results produced with these solutions are lower than the results produced with number sense strategies indicates that students have underdeveloped conceptual knowledge. In today's mathematics curricula, development of conceptual knowledge rather than procedural knowledge is emphasized (Chinese National Mathematics Curriculum, 2001; National Council of Teachers of Mathematics, 2000; Australian Education Council, 1991; MEB, 2005). 
Another component of fluency is mental calculation speed (Russell, 2000, Griffin, 2003, Carr, Taasoobshirazi, Stroud \& Royer, 2011; Walle, Karp \& Bay-Williams, 2010). It was concluded in the research that the mean times of solutions using the number sense strategies such as rounding (44 sec), using matched numbers (50 sec) and adjusting-rearranging $(54 \mathrm{sec})$ were lower than the rule-based algorithmic calculation $(81 \mathrm{sec})$ strategies. The interviews also showed that the students using the algorithmic calculation strategy started mental calculation in addition, subtraction and multiplication from right and others using the number sense strategies started from left. Van de Wall et al. (2012), Heirdsfield and Cooper (2004) stated that as starting mental calculation from left provides a holistic focus on numbers, it increases accuracy of answers and shortens the solution times. It can be accordingly argued that the findings of the research coincide with the findings achieved by Van de Wall et al. (2012) and Heirdsfield and Cooper (2004). Previous studies showed that students with learning difficulty scored lower than normally-developing students in the mental calculation tests with time limitation Jordon, Hanish, 2000; Hanish, Jordon, Kaplan \& Dick, 2001; Jordon, Hanish \& Kaplan, 2003; Anderson, 2010). The longitudinal studies showed that longer calculation times affect mathematical skills in a negative way by years (Anderson, 2010; Jordon et al., 2003). Furthermore, longer durations of calculation make conceptual development difficult as they may cause individual to spend the energy required for thinking in calculations (Schneider \& Stern, 2010; Anderson, 2010; Brynes \& Wasik 1991; Baroody, Feil \& Johnson, 2007; Hallett, Nunes \& Bryant, 2010). Higher number of valid estimations and shorter mean solution times in the solutions using the number sense strategies in the research indicate that number sense strategies increase the mental calculation fluency. The research results coincide with the findings achieved in previous studies (Russell, 2000; Griffin, 2003; Carr, Taasoobshirazi, Stroud \& Royer, 2011; Walle, Karp \& Bay-Williams, 2010). Then, it can be argued that students should be guided towards number sense strategies to support both operation fluency and conceptual development.

It was observed in the study that the elementary school students mostly used the rule-based algorithmic calculation strategy when calculating mentally. Accordingly, teachers can lay emphasis on number sense strategies in in-class activities. Programs for developing operational estimation strategies of students can be also developed, and the effectiveness of these programs can be tested. The studies affecting the relations between number sense strategies and problem-solving strategies can be performed.

\section{References}

Alsawaie, O. N. (2011). Number sense-based strategies used by high-achieving sixth grade students who experienced perform textbooks. International Journal of Science and Mathematics Education, 10(5), 1071-1097.

Altun, M. (2006). ilköğretimde matematik öğretimi. Bursa: Aktüel Alfa Bas. Yay.

Altun, M., Dönmez, N., İnan, H., Taner, M., \& Özdilek, Z. (2001). Altı yaş grubu çocukların problem çözme stratejileri ve bunlarla ilgili öğretmen ve müfettiş algıları. Uludağ Üniversitesi Eğitim Fakültesi Dergisi, 14(1), 211-230.

Andersson, U. (2010). Skill Development in Different Components of Arithmetic and Basic Cognitive Functions: Findings From a 3-Year Longitudinal Study of Children With Different Types of Learning Difficulties. Journal of Educational Psychology, 102(1), 115-134.
Artut, P. D. (2015). Preschool children's skills in solving mathematical word problems. Educational Research and Reviews, 10(18), 2539-2549.

Australian Education Council, \& Curriculum Corporation (Australia). (1990). A national statement on mathematics for Australian schools. Curriculum Press.

Baki, A., \& Kartal, T. (2004). Kavramsal ve işlemsel bilgi bağlamında lise öğrencilerinin cebir bilgilerinin karakterizasyonu. Türk Eğitim Bilimleri Dergisi, 2(1), 27-46.

Baroody, A. J., Feil, Y., \& Johnson, A. R. (2007). An alternative reconceptualization of procedural and conceptual knowledge. Journal for Research in Mathematics Education, 38(2), 115-131.

Benjamin, A. T. (2011). The Secrets of Mental Math. 4840 Westfields Boulevard, Suite 500 Chantilly, Virginia 20151-2299, Printed in the United States of America: The Teaching Company.

Burns, M. (2007). Nine ways to catch kids up. Educational Leadership, 65(3), 16-21.

Byrnes, J. P., \& Wasik, B. A. (1991). Role of conceptual knowledge in mathematical procedural learning. Developmental psychology, 27(5), 777-786.

Carr, M., Taasoobshirazi, G., Stroud, R., \& Royer, J. M. (2011). Combined fluency and cognitive strategies instruction improves mathematics achievement in early elementary school. Contemporary Educational Psychology, 36(4), 323-333.

Creswell, J. W. (2013). Araştırma Deseni. (Translated into Turkish by: S. B. Demir .) Ankara: Eğiten Kitap.

Çekirdekçi, S., Şengül, S., \& Doğan, M. C. (2016). 4. sınıf öğrencilerinin sayı hissi ile matematik başarıları arasındaki ilişkinin incelenmesi.[Examining the relationship between number sense and mathematics achievement of the 4th grade students]. Qualitative Studies, 11(4), 48-66.

Çontay, E. G. (2011). Illköğretim 3. sınıf öğrencilerinin okul matematiğini günlük hayata uygulama becerileri. Pamukkale Üniversitesi Eğitim Fakültesi Dergisi, 30(30), 63-77.

Dede, H. G., \& Sengül, S. (2016). Illkögretim ve Ortaöğretim Matematik Öğetmen Adaylarının Sayı Hissinin Incelenmesi 1. Turkish Journal of Computer and Mathematics Education, 7(2), 285-303.

Dowker, A. (1992). Computational estimation strategies of professional mathematicians. Journal for Research in Mathematics Education, 23(1), 45-55.

Dowker, A. (2005). Early identification and intervention for students with mathematics difficulties. Journal of learning disabilities, 38(4), 324-332.

Elia, I., Gagatsis, A., \& Demetriou, A. (2007). The effects of different modes of representation on the solution of one-step additive problems. Learning and Instruction, 17(6), 658-672.

Elo, S., \& Kyngäs, H. (2008). The qualitative content analysis process. Journal of advanced nursing, 62(1), 107-115.

Er, Z., \& Artut, P. D. (2016). An Investigation of Elementary School Teachers' Sense of Number. US-China Education Review, 6(4), 205-217. 
Erdem, Z. C.., \& Duran, H. (2015). Yetişkinlerin zihinden hesaplama becerilerinin özellikleri üzerine karşılaştırmalı bir çalışma. Turkish Journal of Computer and Mathematics Education, 6(3), 463-482.

Feigenson, L., Dehaene, S., \& Spelke, E. (2004). Core systems of number. Trends in cognitive sciences, 8(7), 307-314.

Geary, D. C. (2003). Learning disabilities in arithmetic: Problem-solving differences and cognitive deficits. Handbook of learning disabilities, 199-212.

Geary, D. C., \& Hoard, M. K. (2005). Learning disabilities in arithmetic and mathematics. Handbook of Mathematical Cognition, p. 253-268.

Gray, E. M., \& Tall, D. O. (1994). Duality, ambiguity, and flexibility: A" proceptual" view of simple arithmetic. Journal for Research in Mathematics Education, 25(2), 116-140.

Griffin, S. (2004). Building number sense with Number Worlds: A mathematics program for young children. Early childhood research quarterly, 19(1), 173180.

Griffin, S. A., Case, R., \& Siegler, R. S. (1994). Rightstart: Providing the central conceptual prerequisites for first formal learning of arithmetic to students at risk for school failure. The MIT Press.

Griffin, S., \& Case, R. (1997). Re-thinking the elementary school math curriculum: An approach based on cognitive science. Issues in Education, 3(1), 1-49.

Gürbüz, R., \& Erdem, E. (2016). Relationship between mental computation and mathematical reasoning. Cogent Education, 3(1), 1-18.

Halmos, P. R. (1980). The heart of mathematics. The American Mathematical Monthly, 87(7), 519-524.

Hanich, L. B., Jordan, N. C., Kaplan, D., \& Dick, J. (2001). Performance across different areas of mathematical cognition in children with learning difficulties. Journal of Educational Psychology, 93(3), 615-626.

Harç, S. (2010). 6. Sınıf öğrencilerinin sayı duygusu kavramı açısından mevcut durumlarının analizi. Unpublished master's thesis, Marmara University, Istanbul.

Heirdsfield, A. M., \& Cooper, T. J. (2004). Factors affecting the process of proficient mental addition and subtraction: Case studies of flexible and inflexible computers. The Journal of Mathematical Behavior, 23(4), 443-463.

Hiebert, J. (1999). Relationships between research and the NCTM Standards. Journal for Research in Mathematics Education, 30(1), 3-19.

Hsieh, H. F., \& Shannon, S. E. (2005). Three approaches to qualitative content analysis. Qualitative health research, 15(9), 1277-1288.

Jordan, N. C., \& Hanich, L. B. (2000). Mathematical thinking in second grade children with different forms of LD. Journal of Learning Disabilities, 33(6), 567-578

Jordan, N. C., Glutting, J., \& Ramineni, C. (2010). The importance of number sense to mathematics achievement in first and third grades. Learning and individual differences, 20(2), 82-88.
Jordan, N. C., Hanich, L. B., \& Kaplan, D. (2003). A longitudinal study of mathematical competencies in children with specific mathematics difficulties versus children with comorbid mathematics and reading difficulties. Child Development, 74(3), 834-850

Kayhan-Altay, M. ve Umay, A.(2011). Sınıf öğretmeni adaylarının hesaplama becerileri ve sayı duyuları arasındaki ilişkinin incelenmesi. e-Journal of New World Sciences Academy, 6(1), 1277-1283.

Keçeci, T. (2011). Matematik kaygısı ve korkusu ile mücadele yolları. Uluslararası Eğitimde Yeni Yönelimler ve Uygulamaları Konferansı'nda sunulmuş sözlü bildiri. Antalya.

Locuniak, M. N., \& Jordan, N. C. (2008). Using kindergarten number sense to predict calculation fluency in second grade. Journal of Learning Disabilities, 41(5), 451-459.

Markovits, Z., \& Sowder, J. (1994). Developing number sense: An intervention study in grade 7. Journal for Research in Mathematics Education, 25(1), 4-29.

MEB (2005). Ilköğretim matematik dersi (1- 5 sınıflar) öğretim programı. Ankara: Devlet Kitapları Basımevi.

Merriam, S. B. (2009). Nitel araștırma desen ve uygulama için bir rehber. Ankara: Nobel Akademik Yayıncılık. Çeviri Editörü: Selahattin Turan.

Miles, M, B., \& Huberman, A. M. (1994). Qualitative data analysis: An expanded Sourcebook. (2nd ed). Thousand Oaks, CA: Sage.

Mohamed, M., \& Johnny, J. (2010). Investigating number sense among students. Procedia-Social and Behavioral Sciences, 8, 317-324.

Natinonal Council of Teachers of Mathematics. (2000). Principles and standards for school mathematics, NCTM, Reston.

Nickerson, S. D., \& Whitacre, I. (2010). A local instruction theory for the development of number sense. Mathematical Thinking and Learning, 12(3), 227-252. Sense. San Diego State University: Theses.

Nunes, T., Schliemann, A. D., \& Carraher, D. W. (1993). Street mathematics and school mathematics. Cambridge University Press.

Olkun, S. (2015). 6-11 Yaş Türk Çocukları Örnekleminde Diskalkuliye Yatkınlığı Ayırt Etmede Kullanılacak Bir Ölçme Aracı Geliştirme Çalışması. 111k545 Nolu TÜBiTAK Projesi, Ankara, Türkiye.

Olkun, S., \& Toluk-Uçar, Z. (2014). Illköğretimde Etkinlik temelli Matematik Öğretimi. Ankara, Eğiten Kitap Yayınları.

Olkun, S., Fidan, E., \& Özer, A. B. (2013). 5-7 yaş aralığındaki çocuklarda sayı kavramının gelişimi ve saymanın problem çözmede kullanımı. Eğitim ve Bilim, 38(169), 236-248.

Olkun, S., Yıldız, E., Sarı, M. H., Uçar, A. ve Turan, A. N. (2014). Ortaokul Öğrencilerinde işlemsel Akıcılık, Çarpım Tablosu ve Sözel Problemlerde Başarı. ilköğretim-Online, 13(4), 1542-1553.

Reys, R. E., Reys, B. J., Nohda, N., \& Emori, H. (1995). Mental computation performance and strategy use of Japanese students in grades 2, 4, 6, and 8. Journal for 
Research in Mathematics Education, 26(4) 304-326.

Rogers, K., \& Large, T. (2012). Şekilli Matematik Sözlüğü. (B. KURT, Çev.) Ankara: Korza Yayıncılık, TÜBiTAK Popüler Bilim Kitapları.

Rubenstein, N (2001). Mental mathematics beyond the middle school. Mathematics Teacher, 94(6), 442-447.

Russell, S. J. (2000). Developing computational fluency with whole numbers. Teaching Children Mathematics, 7(3), 154-158.

Schneider, M., \& Stern, E. (2010). The developmental relations between conceptual and procedural knowledge: A multimethod approach. Developmental Psychology, 46(1), 178-192

Schoenfeld, A. H. (1992). Learning to think mathematically: Problem solving, metacognition, and sense-making in mathematics. In D. Grouws (Ed.), Handbook of research on mathematics teaching and learning (pp. 334-370). New York: MacMillan.

Smith, C.P. (2000). Content analysis and narrative analysis. In Harry T. Reis \& Charles M. Judd (Eds.), Handbook of Research Methods in Social and Personality Psychology (pp. 313-335). Cambridge: Cambridge University Press.

Soylu, Y., \& Soylu, C. (2006). Matematik derslerinde başarıya giden yolda problem çözmenin rolü. İnönü Üniversitesi Eğitim Fakültesi Dergisi, 7(11), 97-111.

Şengül, S. (2013). Sınıf öğretmeni adaylarının kullandıkları sayı duyusu stratejilerinin belirlenmesi. Kuram ve Uygulamada Eğitim Bilimleri, 13(3), 1951-1974.

Şengül, S., \& Gülbağcı Dede, H. (2012). Evaluation of number sense on the subject of decimal numbers of the secondary stage students in Turkey. International Online Journal of Educational Sciences, 4(2), 296-310.

Şengül, S., \& Gülbağcı, H. (2013). 7. ve 8. Sınıf öğrencilerinin sayı hissi ile matematik öz yeterlikleri arasındaki ilişkinin incelenmesi. International Journal of Social Science, 6(4), 1049-1060.

Şengül, S., Dede-Gülbağcı H. (2014). The strategies of mathematics teachers when solving number sense problems. Turkish Journal of Computer and Mathematics Education, 5(1), 73-88.

Ulu, M. (2017a). The Effect of Reading Comprehension and Problem Solving Strategies on Classifying Elementary 4th Grade Students with High and Low Problem Solving Success. Journal of Education and Training Studies, 5(6), 44-63.

Ulu, M. (2017b). Errors made by elementary fourth grade students when modelling word problems and the elimination of those errors through scaffolding. International Electronic Journal of Elementary Education, 9(3), 553-580.

Vaismoradi, M., Turunen, H., \& Bondas, T. (2013). Content analysis and thematic analysis: Implications for conducting a qualitative descriptive study. Nursing \& Health Sciences, 15(3), 398-405.

Van de Walle, J. A., Karp, K. S. \& Bay-Williams, J.M. (2010). Elementary and Middle School Mathematics: Teaching Developmentally. Addison, Wesley, New York. ematics: A learning-teaching trajectory with intermediate attainment targets for calculation with whole numbers in elementary school. Sense Publishers.

Yang, D. C., Li, M. N., \& Lin, C. I. (2008). A study of the performance of 5 th graders in number sense and its relationship to achievement in mathematics. International Journal of Science and Mathematics Education, 6(4), 789-807.

Yang, D. C., Reys, R. E., \& Reys, B. J. (2009). Number sense strategies used by pre-service teachers in Taiwan. International Journal of Science and Mathematics Education, 7(2), 383-403.

Yazgan, Y., Bintaş, J., \& Altun, M. (2002). İlköğretim beşinci sınıf öğrencilerinin zihinden hesap ve tahmin becerilerinin geliștirilmesi. V. Ulusal Fen Bilimleri ve Matematik Eğitimi Kongresi, Orta Doğu Teknik Üniversitesi, Ankara, Türkiye.

Yıldırım, A., \& Şimşek, H. (2016). Sosyal Bilimlerde Araştırma Yöntemleri. Ankara: Seçkin Yayıncılık.

Yıldızlar, M. (2012). Yapılandırmacı Öğretimde Matematik Problemlerini Çözebilme Yöntemleri. Ankara: Pegem Akademi.

Van den Heuvel-Panhuizen, M. (2008). Children learn math- 
This page is intentionally left blank www.iejee.com 